The Graduate History Review 9, no. 1 (2020)

\title{
"Whither Shall We Send Our Son?": A Prosopographical Analysis of Remittance Men in New Zealand
}

\author{
HELEN LEGGATT
}

Abstract: This article represents a unique exploration of the creation and lived experiences of British gentlemen exiled by family to the colonies during the nineteenth century. Known as remittance men, they constituted a small but consistent migrant type to British settler societies, and later became the subject of popular mythology. Remittance men have remained but footnotes in New Zealand historiography and their presence deserves greater scrutiny. Through prosopographical analysis, my research expands current knowledge of the historical contexts in which their identities were forged, and adds their stories to New Zealand's current historiography of the nation's early immigrants.

Note: As part of this research, the author created an Excel spreadsheet containing data analysed for this article. Individuals interested in viewing the data should write and request a copy from the author via helen.leggatt@pg.canterbury.ac.nz

British governments were not averse to shipping social problems abroad in the eighteenth and nineteenth centuries. To date, scholarship has focused on official transportation policies following the 1718 Transportation Act as solutions to the country's burgeoning criminal population, an alternative to the death penalty, and an answer to labour shortage in the American colonies. ${ }^{1}$ In addition, the nineteenth century witnessed attempts to emigrate British vagrant or orphaned children. ${ }^{2}$ Following the loss of the American colonies in the War of Independence, and after a disastrous period during which West Africa was designated a

\footnotetext{
${ }^{1}$ A. Roger Ekirch, Bound for America: The Transportation of British Convicts to the Colonies, 1718-1775 (Oxford, UK: Oxford University Press, 1987). See also: H.

Maxwell-Stewart, "Convict Transportation from Britain and Ireland 1615-1870," History Compass 8 (2010): pp.1221-1242; Christian G. De Vito, Clare Anderson, \& Ulbe Bosma, "Transportation, Deportation and Exile: Perspectives from the Colonies in the Nineteenth and Twentieth Centuries," International Review of Social History 63, S26 (2018): p.2.

${ }^{2}$ Roy Parker, Uprooted: The Shipment of Poor Children to Canada, 1867-1917 (Bristol, UK: Policy Press, 2010), p.6. See also: Elaine Hadley, "Natives in a Strange Land: The Philanthropic Discourse of Juvenile Emigration in Mid-Nineteenth-Century England," Victorian Studies 33, no. 3 (1990): p.412.
} 
convict destination, Australia became Britain's primary penal colony in $1788 .^{3}$ As such, the relationship between transportation and settlement developed over time.

Less understood is the development and impact of informal networks of emigration that formed over the nineteenth century. Whereas official emigration programmes were institutionally led by governments or charity organisations, another powerful institution of enforced emigration emerged - the family. New Zealand was not a destination in Britain's programme of punitive transportation but, in the mid-1800s, it became a destination to which profligate and socially embarrassed younger sons were sent. Dubbed "remittance men," due to the regular payments sent by family to keep them abroad, the exiled sons found themselves at the centre of emerging nativist debates about unwelcome migrants. The preferred destinations were colonial outposts such as Australia, Canada, and New Zealand. Strictly enforced and observed, these family policies of emigration, driven by expectations of masculinity, class, and social mores, could be as persuasive and powerful as any legislation or government policy.

The presence of remittance men in New Zealand raises important questions, three of which I address in this article. First, when and for what period are individuals identified as remittance men visible across the British colonies of Australia, Canada and New Zealand? Second, which historical contexts contributed to this social type's formation? Finally, what can prosopographical analysis reveal about the socio-demographic make-up of remittance men, and their behaviour and fates in New Zealand? Such questions are absent from New Zealand historiographies of society and migration. Until recently, historians and New Zealanders alike have suffered what Jock Philips and Terry Hearn describe as a "collective amnesia" regarding the backgrounds of settler ancestors. This indifference to acknowledging ancestry beyond the ship on which ancestors arrived might, they speculate, result from a desire to forget regrettable pasts or snub ancestors "thrown out of their families after a youthful misdemeanour." ${ }^{4}$ No scholarship has investigated the temporal visibility of remittance men in colonial New Zealand. This is understandable given the paucity of scholarly research focused on remittance men. Instead, the historiography tends towards biography and

\footnotetext{
${ }^{3}$ Clare Anderson, "Transnational Histories of Penal Transportation: Punishment, Labour and Governance in the British Imperial World, 1788-1939," Australian Historical Studies 47, no. 3 (2016): pp.381-383.

${ }^{4}$ Jock Phillips and Terry Hearn, Settlers: New Zealand Immigrants from England, Ireland and Scotland 1800- 1945 (Auckland, NZ: Auckland University Press, 2013), p.3.
} 
The Graduate History Review 9, no. 1 (2020)

local and oral histories. This is due in part to the challenges inherent in identifying remittance men - the applied label has generally been dependent on subjective observations rather than established facts.

Answers to the questions posed in this article are found using a mixed methods approach. First, a survey of the English-speaking press across four countries-Australia, Britain, Canada, and New Zealandduring the period between 1870 and 1960, searching the keywords "remittance man" and "remittance men," allows temporal analysis of their presence within colonial societies. While this method allows for a broad transnational comparison of the presence over time of remittance men by colony, it is acknowledged this method is not a catch-all scenario. However, it is adequate for this analysis given the difficulties identifying individual remittance men. Second, prosopographical analysis of 166 remittance men identified in New Zealand explores their backgrounds and behaviours that resulted in their lives as remittance men, as well as their subsequent lived experiences. This unique research adds to current understandings of New Zealand's social history by analysing a littleknown social type and inserting them into the colony's migration history.

Erik Olssen observed that the archetypal remittance man was "a recurring figure in older accounts of the nineteenth-century" but has "long since disappeared from the literature." ${ }^{5}$ This anonymity in the present requires a pause for definition. The phrase "remittance man" was not a label adopted by those to whom it applied. Neither was it in general use within official and public records-hence Karl F. Zeisler's observation that "the thing about a remittance man...is that no one ever knows for sure whether or not he is a remittance man." ${ }^{6}$ Rather, the phrase became associated with a specific, particularly visible socio-demographic group of emigrants to the British colonies in the nineteenth century. In terms of official definition, a remittance man was "an emigrant who live[d] abroad (esp. in a former British colony) supported by remittances of money from relatives at home; spec. one considered undesirable at home." ${ }^{7}$ The term remittance man was in popular use in Australasia by the 1880 s and entered

\footnotetext{
${ }^{5}$ Erik Olssen, "Where to from Here? Reflections on the Twentieth-Century Historiography of Nineteenth Century New Zealand," New Zealand Journal of History 26, no. 1 (1992): p.74.

${ }^{6}$ Karl F. Zeisler, "Mr Langhorne - a Prairie Sketch," Quarterly Review of the Michigan Alumnus 65 (1959): p.229.

${ }^{7}$ Oxford English Dictionary, "Remittance Man," (Oxford: Oxford University Press, July 2018).
} 
the dictionary Austral English in $1898 .^{8}$ The phrase remittance man appeared in the New Zealand press for the first time in March 1876, and was used in a humorous manner that assumed readers' familiarity with the term:

We learn from the Wellington Post that one of the first uses made of the Australian cable was by a remittance man. He telegraphed to his friends in England "Lend me £20." The answer received was "Paid for your telegram and this-balance per mail." He is now waiting for the mail that will bring him about enough to acknowledge the receipt by post. ${ }^{9}$

The phrase "remittance immigrant" is found in the Australian press as early as July 1876 , and in the British press a decade later. ${ }^{10}$ However, a far earlier mention can be found in 1868 in the Canadian press. The term is used in the short conundrum "Why do the Subscribers of the Mechanic's Institute increase so slowly? Because the Colony is full of Remittance men." ${ }^{11}$ The fact that the phrase "remittance man" was used in the press suggests readers were familiar with the archetype. Despite being a social role relatively unheard of today, the remittance man was clearly a recognised character within early colonial societies.

British colonies were considered suitable locations where sons of the upper-class could — with the necessary skills, temperament, and family capital-embark on successful colonial careers far from the rigid behavioural expectations of Victorian English upper-class society. New Zealand was furthest from Britain's shores and sparsely populated with upper-class migrants. This combination of geographic isolation and demographics could virtually guarantee a son would not return, and would be unlikely to be recognised if he did. Two articles appeared in the journal The Nineteenth-Century in 1883, both written by Major-General

\footnotetext{
${ }^{8}$ Edward E. Morris, Austral English: A Dictionary of Australasian Words Phrases and Usages, with Those Aboriginal-Australian and Maori Words Which Have Become Incorporated in the Language and the Commoner Scientific Words That Have Had Their Origin in Australasia (London: Macmillan, 1898).

9 "News," West Coast Times, 4 March 1876, p.2.

10 "A Holiday in the Rockies," Pall Mall Gazette, 10 February 1886, p.11.

11 "Original Conundrums," Victoria Daily British Colonist, March 14 1868, 3.
} 
Feilding. ${ }^{12}$ Feilding addressed two questions common among upper-class parents-"What Shall We Do With Our Son?" and "Whither Shall We Send Our Son?" Feilding's answer to the first was a lengthy tract that can be condensed to one word-emigrate. ${ }^{13}$ To the second he elucidated the "merits and demerits" of various British colonies to "assist parents and guardians in making the selection most befitting the financial condition, as well as the constitution and natural tastes, of those whom they seek to start in life."14 Feilding provided an unfeasibly long list of skills he recommended gentlemen acquire to be successful in the colonies, including the laws and principles of agriculture, animal husbandry, horsemanship, irrigation construction, carpentry, hydraulics, seamanship, natural science, chemical science, fishing, curing meat, first aid, geology and mineralogy. Experienced colonists, such as Ernest Albin Smith, refuted Feilding's advice. It was possible, wrote Smith, a British civil servant who emigrated to Queensland at age 30 and gained experience in the breeding and raising of sheep before embarking on a career as a sport journalist, that "sober, industrious and intelligent lads of good birth and education" would find it easier to secure employment in Australia than in the overcrowded professional market in Britain. However, he continued, "idle, weak, or intemperate" sons or a "mauvais sujet" exiled by an embarrassed family could expect "pecuniary ruin" and "social degradation."15 Feilding's knowledge of colonial life informed his determination that the acquisition of relevant skills was key to success in the colonies. He would later become a supporter of the Colonial College in Britain. ${ }^{16}$ Similarly, Smith's experience highlights that success in the colonies required self-discipline and hard work.

Even with the required skills, a remittance man's class and its associated affectations were considered a hindrance in colonial society. Such men would find themselves among a population lacking the

\footnotetext{
${ }^{12}$ During 1870-1871, the then Honourable Lieutenant-Colonel William Henry Adelbert Feilding, son of the $7^{\text {th }}$ Earl of Denbigh, toured Australia and New Zealand as the chief representative of the Emigrants' and Colonists' Aid Corporation. The Corporation was a private English body, led by the Duke of Manchester, set up to settle a group of people selected from the unemployed agricultural labouring class in Britain.

${ }^{13}$ William H. A. Feilding, "What Shall I Do With My Son?" The Nineteenth Century 13 (1883): pp.578-586.

${ }^{14}$ William H. A. Feilding, "Whither Shall I Send My Son?" The Nineteenth Century 14 (1883): p.65-77.

15 "Major-General Feilding's Ideas on Upper Class Emigration," The Brisbane Courier, 7 February 1884, p.3.

${ }^{16}$ J. A. Mangan, 'Benefits Bestowed'?: Education and British Imperialism (Oxford, UK: Routledge, 2012), p.199.
} 
"plebeian deference" from which a British gentleman's status was derived. ${ }^{17}$ This was particularly so in the "new" colonies of Australia, Canada, and New Zealand, wrote Herbert Branston Grey, Wintonian, graduate of Oxford, and former headmaster of Bradfield College. There they would not reside among "lower or more submissive races" as in India or Africa. Instead, they would "encounter a people entirely free from subservience to rank or wealth, a people intolerant therefore of dictation or condescension, in whose lives...the distinction between class and class has for all practical purposes disappeared."18 Instead, as Smith observes, in the new colonies it was an individual's "actions and capabilities" on which they were judged and not a genealogy of esteemed "ancestors and relations."

Smith's opinions are echoed by New Zealand historian, Jim McAloon, who asserts that, among New Zealand's upper- and middleclass settlers, the dominant ethic "was one of individual effort and selfimprovement." ${ }^{19}$ Drawing on their various colonial and educational experiences, the opinions of Feilding, Smith, Grey, and Duthie concur. Relying on status for success and respect without the skills or experience deemed necessary in a frontier environment was risky. William Swainson, New Zealand's second attorney general, suggested "for candidates for Government employment, for young men who have neither capital nor skill, and who are too proud or too weak to earn their bread by the sweat of their brow New Zealand cannot be recommended."20

In addition to upper-class attitudes and a lack of relevant skills, the regular receipt of financial support further distanced remittance men from the "rough and tough" colonial masculinities surviving on "fifteen pounds of meat a week and no bed sheets."21 Paid in various instalment periods, remittances varied from $£ 1$ to $£ 4$ per week. ${ }^{22}$ Reverend D. Wallace Duthie wrote of his colonial experience in South Africa and

\footnotetext{
${ }^{17} \mathrm{Jim}$ McAloon, "Class in Colonial New Zealand: Towards a Historiographical Rehabilitation," New Zealand Journal of History 38, no. 1 (2004): p.6. See also Monica Rico, "Sir William Drummond Stewart: Aristocratic Masculinity in the American West," Pacific Historical Review 76, no. 2 (2007): p.167.

${ }^{18}$ Herbert Branston Gray, The Public Schools and the Empire (London: Williams \& Norgate, 1913), p.20.

${ }^{19}$ McAloon, "Class in Colonial New Zealand," p.13.

${ }^{20}$ William Swainson, New Zealand and its Colonization ( London: Smith, Elder and Co., 1859), p.193.

${ }^{21}$ James Belich, Making Peoples: A History of the New Zealanders: From Polynesian Settlement to the End of the Nineteenth Century (Auckland, NZ: Allen Lane, 1996), p.429.

${ }^{22}$ Helen Leggatt, "Remittance Man Database," (2018).
} 
Australia that the drive for success among remittance men was diminished because remittances "relieve him of the need of finding employment" or "keeping it by his sobriety and good conduct." ${ }^{23}$ Neither was employment in the professions easily found in colonial New Zealand. As early Canterbury pioneer and astute observer Lady Barker relays in her memoires, within the country's frontier society "the machinery of civilisation is reduced to the most primitive scale." ${ }^{24}$ A sufficient income may explain how some remittance men were able to maintain the appearance of a "dandy" — at least initially_among settlers whose garb, plain but of good quality, was more suited to colonial life. ${ }^{25}$ Gerard Taylor, the son of a wealthy British doctor, "astonished" the Sampson family in Taranaki when he arrived on their small farm wearing "top hat and tails, finely worsted trousers, [and] gloves, and carr[ying] a gold mounted cane." ${ }^{26}$ William Howlett, the son of an English clergyman, "wore white silk suits" 27 and George John Fisher, whose family seat was Walton Hall in Yorkshire, was also renowned for his white suits. ${ }^{28}$ These are likely the type of upper-class men that were given "lordly" nicknames such as "Dandy Jack" or "The Marquis."29 However, it is likely these outward trappings of wealth did not last among those who could not find employment, or for whom the only procurable work was manual labour. Certainly, Taylor is remembered in later years as wearing "grubby dungarees and an old felt hat," and working on a farm..$^{30}$ British writer Charles Wentworth Dilke recalled a "Life Guardsman" who wore his smock "like a soldier's tunic and his cap stuck on one ear in Windsor fashion" and men who, despite their military and university education and "polished manners," looked to be "the roughest of the rough."31 Lady

${ }^{23}$ D. Wallace Duthie, "The Remittance Man," Nineteenth Century 46 (1899): p.828.

${ }^{24}$ Lady M.A. Barker, Station Amusements in New Zealand (London: William Hunt \& Co., 1873), p.17.

${ }^{25}$ George Butler Earp, New Zealand: Its Emigration and Gold Fields (London: George Routledge \& Co., 1853), p.226.

${ }^{26}$ Hartley, Colonial Outcasts, p.135.

${ }^{27}$ Ibid., p.106.

${ }^{28}$ Hartley, Colonial Outcasts, p.64.

${ }^{29}$ Jack Adam, Vivien Burgess and Dawn Ellis, Rugged Determination: Historical Window on Swanson, 1854-2004 (Auckland, NZ: Swanson Residents \& Ratepayers Assn, 2004), p.52.

${ }^{30}$ Hartley, Colonial Outcasts, p.136.

${ }^{31}$ Charles Wentworth Dilke, Greater Britain Volume 1 (London: Macmillan and Co., 1868), Project Gutenberg, retrieved 8 May 2020 from http://www.gutenberg.org/ebooks/41755. 
Barker observed that "at the end of six months their clothes [began] to look shabby." ${ }^{32}$

Despite their presence within British colonies, remittance men remain relatively invisible within historiographies of New Zealand migration and society. A solitary book is dedicated to the topic, Nell Hartley's Colonial Outcasts: A Search for the Remittance Men. Hartley makes explicit her aim of countering the negative stereotype associated with remittance men, "a myth which did not include the positive aspects in the lives of many of these men," and hoped to create "a base for social historians to build on." ${ }^{33}$ However noble her aim, most of Hartley's biographies contain behaviours inconsistent with late nineteenth-century social mores, both before and after banishment. Such misdemeanours appear tame compared with modern values, but were intolerable in nineteenth-century upper-class society. While some individuals in Hartley's research did reform their ways in New Zealand, many biographies refer to deviant behaviour including fraud, theft, alcoholism, insolvency, vagrancy, and the fathering of illegitimate offspring. Hartley barely manages to rehabilitate the reputation of remittance men in New Zealand.

Within wider historiographies of New Zealand society, discussions of remittance men remain footnotes within larger narratives. Writing of social relations among men in the mining town of Te Aroha, Philip Hart describes "high-spirited young men sent to the colonies by their exasperated fathers and paid a regular sum to remain there." ${ }^{34}$ An unpublished transcript of a talk by Rollo Arnold provides a more generous description of the "remittance type" who "were a more important element in our founding stock than is commonly realised." Arnold uncovered the earliest mention of New Zealand's "remittance type" within shipboard diaries of the 1840s and 1850s. "Some of these enforced emigrants made good," writes Arnold, "most added colour to colonial life, few were without redeeming features." ${ }^{35}$ Miles Fairburn suggests remittance men symbolised "the absolute inconsistency between morality, status, and

\footnotetext{
${ }^{32}$ Barker, Station Amusements, p.17.

${ }^{33}$ Hartley, Colonial Outcasts, p.17.

${ }^{34}$ Philip Hart, "Social Relations and Class Divisions in the Te Aroha District," (Historical Research Unit - University of Waikato, 2016), p.27.

${ }^{35}$ Rollo Arnold, "Exodus from the Fringes: Emigrants to New Zealand 1839-1879,"

Typescript of a talk, n.d., https://sites.google.com/site/rolloarnold/migration (accessed 12 June 2018), p.7.
} 
The Graduate History Review 9, no. 1 (2020)

material success in New Zealand." ${ }^{136}$ They challenged an idealised social order borne of thriftiness and moderation of behaviour and consumption. James Belich suggests New Zealand was a "favoured destination for 'remittance men."'37 Erik Olssen observes that "although there is no good historical study of the phenomenon, in the late-nineteenth century New Zealanders were especially fascinated with 'remittance men."'38 The closest that researchers have come to analysing remittance men and their behavioural traits is in Jennifer Kain's investigation of "the ne'er-do-well" in New Zealand migration, and "how moral judgments about abnormal behaviours translated into political policy making." ${ }^{139}$

Remittance men were despatched to distant shores for behaviour that would undermine a family's reputation and social standing. Misdemeanours varied from "an officer not paying his mess bills," "getting a maid 'into trouble'" or, for a clergyman's son, a lack of piety. Alternatively, a remittance man may have been "addicted to drink, or a gambler." 40 John Nathaniel Williams (1878-1915), son of Sir Robert Williams, was educated at Eton and New College, Oxford. He acquired a penchant for gambling and left Oxford with bookmaker and moneylender debts totalling $£ 4,500$, which his father settled. For the following six years, Williams socialised with high society at fashionable London venues such as Cox's Hotel on Jermyn Street, resulting in betting debts of more than $£ 12,000$ - debts that were again settled by his father. Williams declared bankruptcy in 1909 , owing over $£ 20,000$. At his bankruptcy hearing, reported in the press, his representative declared him "a young man who became obsessed with a desire to bet, the fever having attacked him." ${ }^{41}$ Williams' great-nephew Sir Philip Williams recounts that the gambler's father "gave his son an ultimatum[:] to live abroad as a Remittance Man or be disinherited completely." 42 Williams departed

\footnotetext{
${ }^{36}$ Miles Fairburn, The Ideal Society and Its Enemies: The Foundations of Modern New Zealand Society, 1850- 1900 (Auckland, NZ: Auckland University Press, 1989), p.73.

${ }^{37}$ James Belich, Making Peoples, p.326.

${ }^{38}$ Erik Olssen, "Where to from Here? Reflections on the Twentieth-Century Historiography of Nineteenth-Century New Zealand," New Zealand Journal of History 26, no. 1 (1992): p.74.

39 Jennifer Kain, "The Ne'er-Do-Well: Representing the Dysfunctional Migrant Mind, New Zealand 1850-1910," Studies in the Literary Imagination 48, no. 1 (2015): p.78. ${ }^{40}$ Monica Rico, Nature's Noblemen, p. 77.

41 "Young Man's Betting Losses," Globe (UK), 9 February 1909, p.5.

42 "John Nathaniel (Nat) Williams," Waihi Museum: www.waihimuseum.co.nz/museumand-research/world-war-i/john-nathaniel-williams.
} 
England for New Zealand aboard the Tainui on 21 July $1911{ }^{43}$ John Nathaniel Williams represents the typical, privileged remittance man who squanders time and money on self-gratification, leaving his family, embarrassed by his behaviour made public in the press, to settle his debts and remove him from British society.

It was not just reckless behaviour that could result in exile. Letting down a proud family tradition or a failing career could also have consequences. William Montagu Davenport Howes was the youngest son of a family long associated with the $51^{\text {st }}$ ( $2^{\text {nd }}$ Yorkshire, West Riding, The King's Own Light Infantry) Regiment. His father George had served in the Regiment, attaining the rank of Captain, as had his grandfather. ${ }^{44}$ In 1903, Howes appeared in the New Zealand press in an article about his conviction in 1900 for assault and use of insulting language. In the article, Howes was represented as an ex-Army Officer and veteran of the first Boer War. ${ }^{45}$ However, an examination of his army record reveals a different reality. In 1881 Howes signed a short service attestation (Form B-265) on which he noted his trade as "clerk," and that he had previously been rejected as unfit for Her Majesty's service. Written in pencil next to his admission of rejection is "defective vision." Nonetheless, his impairment was disregarded and a handwritten note at the foot of the attestation form may explain why. It reads "By Authority dated Horse Gds 14.2.81," and it is interesting to note that his father, George Fuller Howes, was employed in the Adjutant General's Dept, Horse Guards, in 1851. ${ }^{46}$ The younger Howes was not an officer. He enlisted as a Private in the $62^{\text {nd }}$ Brigade of Infantry (later The Duke of Edinburgh's (Wiltshire Regiment)). Furthermore, his military record makes no mention of service in the first Boer War, which ended one month after he enlisted. Instead, William spent eighteen months in Malta and two years in the West Indies, while the remaining two months of his three year and three months' service were spent in Britain. He spent a large proportion of his military career in hospital care-a total of 477 days - for "general debility." 47

\footnotetext{
43 "Passenger Lists Leaving UK 1890-1960," database, FindMyPast: www.findmypast.com, entry for passenger Jonathan Nathaniel Williams, Tainui, 21 July 1911.

${ }^{44}$ H. G. Hart, The New Annual Army List, and Militia List (London: John Murray, 1863), p.638, National Library of Scotland, retrieved 4 May 2020 from https://digital.nls.uk/105741571

45 "An Ex-Army Officer in Trouble: A Sad Case," Auckland Star, 4 May 1903, p.2.

46 "1851 England Census," database, Ancestry, https://www.ancestry.com, entry for George Fuller Howes.

47 "British Army Service Records," database, FindMyPast, www.findmypast.com, entry for William Montague Davenport Howes, 23 February 1881.
} 
The Graduate History Review 9, no. 1 (2020)

William was given the opportunity of an army career through his family's military ties. His failure to live up to expectations, due to physical and mental frailty, almost certainly disappointed his family and led to his despatch to New Zealand.

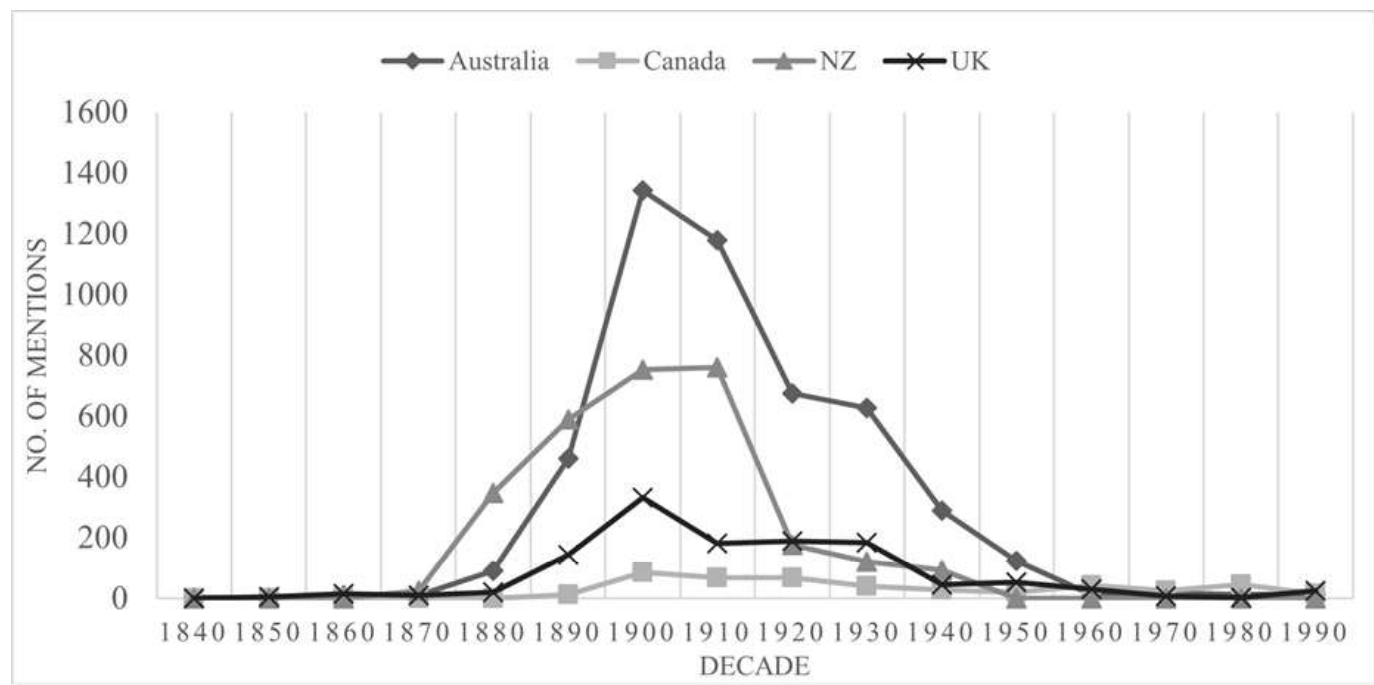

Figure 1: Keywords "Remittance Man" and "Remittance Men" in the English-speaking Colonial Press. Sources obtained through https://trove.nla.gov.au, https://paperspast.natlib.govt.nz, https://www.britishnewspaperarchive.co.uk.

So, when did remittance men begin to appear in the colonies? Surveys of English-language newspapers in Australia, Britain, Canada, and New Zealand go some way towards answering this question. As Figure 1 illustrates, there is a temporal trend common across all colonies relating to the visibility of remittance men. This suggests that analysis of the historical contexts during which press scrutiny of remittance men in the colonies waxes and wanes can inform understandings of the archetype's putative lifespan. To this end, the temporal trends evident in popular understandings of "remittance men" will be discussed using three key phases, largely focusing on Britain, the country of origin for the majority of the emigrants.

Phase One represents the period from 1870 to the outbreak of World War I. During this period, popular attention paid to remittance men in the colonial press commences and rises significantly, peaking between 1905 and 1910. In terms of economic and social change, this phase is significant. First, during the last quarter of the nineteenth century, wealthy British landowners from the aristocracy and upper-classes became increasingly economically vulnerable. The opening of the American West 
to farming, coupled with technological advances in agriculture and transportation, led to cheap cereal imports flooding the British market. Between 1870 and 1895 wheat prices halved, and the volume of imported wheat doubled. Britain's landowners saw their land values decrease; gross land value dropped from $£ 104 \mathrm{~m}$ in 1869 to $£ 62 \mathrm{~m}$ from 1894 to the turn of the century. Similarly, agricultural revenues fell from one-fifth of national income in 1850 to one-sixteenth in $1900 .^{48}$ David Cannadine and F. M. L. Thompson consider the agricultural depression a major cause of decline in the fortunes of the aristocracy and landed gentry. ${ }^{49}$ The fact that Britain "ceased to provide them with adequate financial support" meant the gentry's attention turned to the colonies. ${ }^{50}$

Second, entry into careers traditionally occupied by younger sons of the aristocracy and landed gentry, such as the civil service and military, came under political scrutiny. Reforms sought to democratise entry into these careers, disrupting expectations among the upper-classes of obtaining such employment. With these reforms, it was intended that professional success based on money, connections, and social status would make way for success based on merit, ability, and education. ${ }^{51}$ Beginning in the $1870 \mathrm{~s}$, the civil service introduced "open competition," making way for the accomplished, privately-educated upper-middle classes to enter professions traditionally populated by the upper classes. ${ }^{52}$ The Cardwell reforms of 1870 attempted to abolish the purchase of commissions - a system that, while illegal, had long been tolerated in the British army. "Notice to gallant but stupid young gentlemen," wrote Punch, advising that sons of the gentry had until the end of October 1871 to buy a commission, after which they would be "driven to the cruel necessity of deserving them." ${ }^{53}$ However, the degree to which Cardwell's reforms affected class diversity within the officer corps has been widely debated. The general consensus is that class, public schooling, and social ties remained key to the acquisition of a commission until at least World War Two. ${ }^{54}$ Cardwell's reforms may have "opened the army's door to new

\footnotetext{
${ }^{48}$ P. J. Cain and A. G. Hopkins, British Imperialism: Innovation and Expansion, 16881914 (London: Longman, 1993), p.111.

${ }^{49}$ Cannadine, Decline, p. 293.

${ }^{50}$ Cannadine, Decline, p.429.

${ }^{51}$ Cannadine, Decline, p. 239.

${ }^{52}$ Cannadine, Decline, p.239.

53 "Punch's Essence of Parliament," Punch, 5 August 1871, p.45.

${ }^{54}$ See: Albert V. Tucker, "Army and Society in England 1870-1900: A Reassessment of the Cardwell Reforms," Journal of British Studies 2, no. 2 (1963): 110-41. C. B. Otley, "The Educational Background of British Army Officers," Sociology 7, no. 2 (1973): 191209; Thomas F. Gallagher, "'Cardwellian Mysteries': The Fate of the British Army
} 
The Graduate History Review 9, no. 1 (2020)

sectors of the middle class who had acquired the appropriate social cachet of a public school education," writes historian C.B. Otley, but abolition of purchase "did not shut the door to the traditional elitist sources of supply." ${ }^{55}$ Remittance men embroiled in social scandal might find it challenging to enter the Army with a commission after the reforms, but their social standing and networks continued to place them in favourable positions to do so.

The clergy was another profession that younger sons commonly expected to enter. This was facilitated by landowning fathers' rights of advowson - the ability to present to a Bishop their nominee for a parish priest with its accompanying benefices such as a dwelling and income from tithes. Younger sons of landowners were commonly gifted such benefices as a living. A Royal Commission in 1879 reported abuses associated with such patronage and recommended changes to protect parishes from the appointment of immoral, aged, or incompetent clergy. ${ }^{56}$ As lands were broken up after the agricultural depression, advowsons were disposed of, or became unpopular among sons of the gentry as parishes fragmented and associated income decreased. ${ }^{57}$ Later, the Benefices Act 1898 ensured Bishops were able to prevent "unsuitable appointments." ${ }^{58}$ Ecclesiastical reform and a focus on moral suitability precluded automatic entry into the clergy by younger sons of an unsuitable character.

Decreased land assets, income, and the professionalisation of careers traditionally reserved for younger sons left British society with "surplus gentlemen." ${ }^{59}$ Families looked to the colonies as locations where their sons' futures might be forged. However, their sons' goals differed. Some went for fun and adventure away from "the stern gaze of the parental

Regulation Bill, 1871," The Historical Journal 18, no. 2 (1975): 327-48; Anthony P.C. Bruce, The Purchase System in the British Army, 1660-1871 (London: Royal Historical Society, 1980), pp.157-158; Edward M. Spiers, The Late Victorian Army, 1868-1902 (Manchester, UK: Manchester University Press, 1992), p. 18;

${ }^{55}$ C. B. Otley, "The Social Origins of British Army Officers," Sociological Review 18, no. 2 (1970): p.234

${ }^{56}$ Royal Commission on the Law Practice of Sale Exchange Resignation of Ecclesiastical Benefices, Report of the Commissioners Appointed to Inquire into the Law and Existing Practice as to the Sales, Exchange, and Resignation of Ecclesiastical Benefices (London: George Edward Eyre \& William Spottiswoode, 1879) https://hdl.handle.net/2027/umn.31951002137499c.

57 W. A. Evershed, "Party and Patronage in the Church of England, 1800-1945: A Study of Patronage Trusts and Patronage Reform," (ProQuest Dissertations Publishing, 1986), p.37.

${ }^{58}$ Cannadine, Decline, p. 259.

${ }^{59}$ Rico, Nature's Noblemen, p.52. 
eye," and some to make a new life abroad. There were also those sent "to live down disgrace, and often became more unacceptable in the process." ${ }^{60}$ Writing in 1872, Charles Henry Eden, a British migrant and greatgrandson of Sir Robert Eden, third baronet of West Auckland, observed that:

Every profession and calling in England being already overcrowded, and those unfortunate beings, younger sons, continuing to be born, there can be no doubt that these and other portionless individuals must direct their attention to the only outlet left open, viz. our Colonies. ${ }^{61}$

Phase Two, the period 1915-1945, sees reports of remittance men across the colonial press decline. As Britain entered war in August 1914, sons of the aristocracy responded to a key ethic of their statusnoblesse oblige. ${ }^{62}$ They died in "disproportionate numbers"- one in five killed in action were British peers or their sons, compared to one in eight British soldiers. ${ }^{63}$ By January 1916, 800 of those listed in Debrett's had been killed or wounded in action, and 100 peerages or baronetcies were endangered without heirs. ${ }^{64}$ For many remittance men "the coming of war was a godsend," as it provided them the opportunity to "do noble service in a worthy cause" and be reunited with their family that must surely embrace them after they had "risked their life for king and country." ${ }^{65}$ If war was indeed a factor in the decreasing visibility of remittance men in New Zealand during this period, the reasons for it are unclear due to the lack of case studies on which to base conclusions. One explanation might lie in remittance men's patriotism and sense of duty. This was certainly a reason cited by many who knew remittance men in Alberta, Canada at the start of the Great War. ${ }^{66}$ Just one remittance man in the database, the aforementioned bankrupt gambler John Nathaniel Williams, serves as an

\footnotetext{
${ }^{60}$ Cannadine, Decline, pp.429 - 30.

${ }^{61}$ H. C. Eden, My Wife and I in Queensland (London: Longman, Green \& Co., 1872), p.1.

${ }^{62}$ Richard Carr and Bradley W. Hart, "Old Etonians, Great War Demographics and the Interpretations of British Eugenics, c.1914-1939," First World War Studies 3, no. 2 (2012): p.227.

${ }^{63}$ Rico, Nature's Noblemen, p. 213.

64 "Losses of the Peerage," Gloucestershire Chronicle, 1 January 1916, p.7.

${ }^{65}$ Zuehlke, Scoundrels, p.187.

${ }^{66}$ Ryan Flavelle, "Alberta Remittance Men in the Great War," in The Frontier of Patriotism: Alberta and the First World War, eds. Adriana A. Davies \& Jeff Keshen (University of Calgary Press, 2016), p.107.
} 
example. Removed to New Zealand by his father for significant gambling debts, John did not return to Britain, where he had been recommended for a lieutenant's commission in the Army, at the outbreak of World War One. Instead he joined his friends from Waihi in the ranks of the New Zealand Expeditionary Force ${ }^{67}$ His appearance in the war diary of his friend, Gerald "Tad" Morpeth, was usually associated with lively stories of antics on leave, discipline for late returns to camp, and Williams' fondness for playing bridge. ${ }^{68}$ Private Williams died on 25 April, 1915 during the landing of the New Zealand Expeditionary Force at Gaba Tepe, Gallipoli. According to his entry in De Ruvigny's Roll of Honour, he died "setting a most gallant example," and that by "dying in the ranks" he had "done more for this force and perhaps for the Empire than he would have done as a commissioned officer." 69

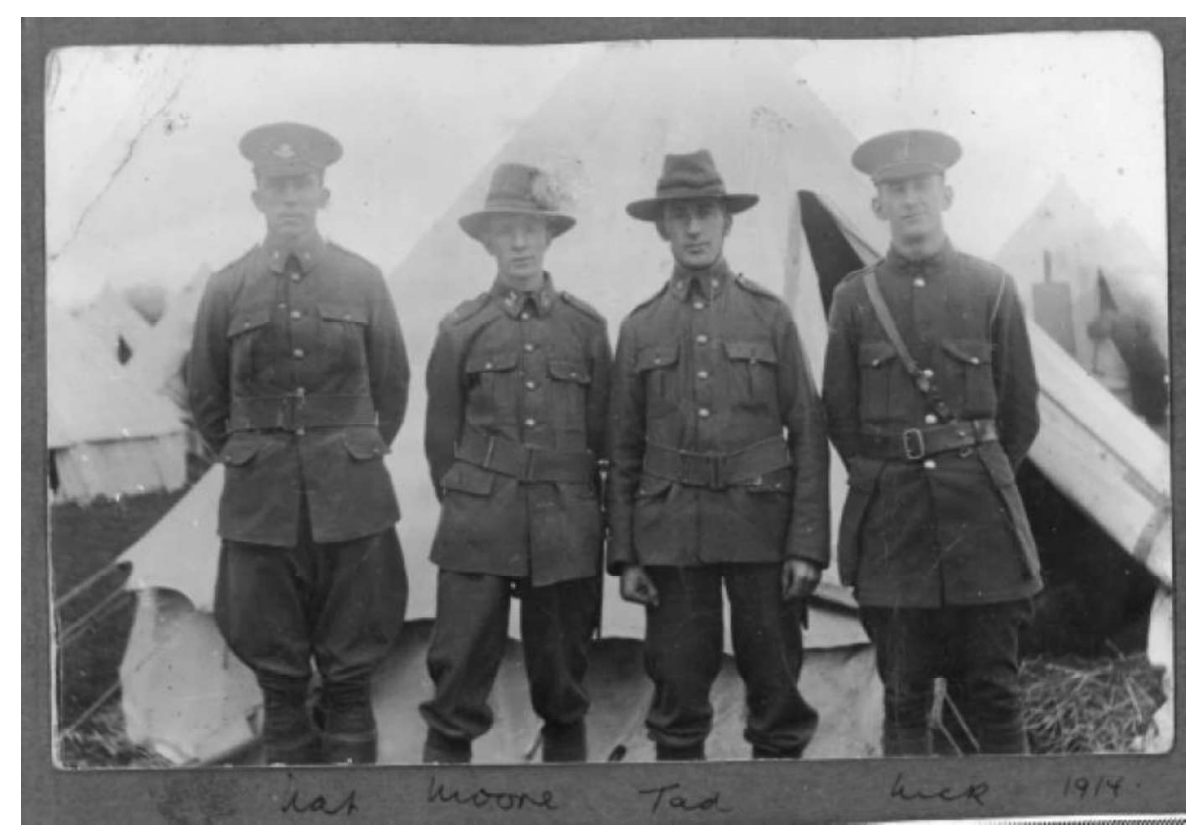

Figure 2: Private John Nathaniel Williams (far left), 1914. Source: "The Morpeth Waiheathens (WWI) 14-0333," Tauranga Memories: Remembering War, Tauranga City Libraries, New Zealand. http://tauranga.kete.net.nz/en/remembering_war.

67 "On Active Service," New Zealand Herald, 17 July 1915, p.8.

${ }^{68}$ Allan Philip Morpeth, The "Waiheathens" at Gallipoli, Tauranga City Libraries Research Collections, 2008:

https://www.tauranga.kete.net.nz/remembering_war/documents/show/429-ebook-epubformat-the-waiheathens-at-gallipoli-by-allan-p-morpeth.

69 "De Ruvigny's Roll of Honour Volume 1," database, Ancestry,

https://www.ancestry.com, entry for John Nathaniel Williams, 380. 
Contributing to the decline in visibility of remittance men between 1915 and 1945 was the abolition of the law of primogeniture. Primogeniture had previously ensured large estates remained intact and passed from father to eldest surviving son. ${ }^{70}$ Among the upper middle classes, the eldest would inherit the family business. ${ }^{71}$ Introduction of the Administration of Estates Act 1925 allowed spouses to inherit, and allowed land and personal effects to be distributed among male and female children. No longer were younger sons or daughters reliant on allowances from the income of a family's estate or an advantageous marriage. Younger sons were now eligible to inherit part of a family estate or business, and less likely to find themselves being despatched abroad with remittances to make their own way in life.

During Phase Three, 1946-1960, reports of remittance men in the colonial press all but disappear. The remaining narratives represent a change from their existence in society to popular mythology. The 1954 film The Beachcomber, based on Somerset Maugham's short story "Vessel of Wrath," features Ginger Ted, a "dissolute remittance man." Ted is "always getting into trouble, frequently drunk, brawling in bars, [and] behaving disgracefully to women" and has a "foul mouth" and "rumpled appearance." However, he eventually finds love and is reformed. ${ }^{72}$ The 1959 musical, Kookaburra, set in Australia and based on a play by Joyce Dennys, featured an "alcoholic, wistful and well-read" remittance man who is "crumpled" and "bloodshot."73 On learning he is a baronet, the character eventually returns to England to take up his seat in the Cotswolds. Fictional works include End in Sight, a novel about an English remittance man in Spain who is a survivor of the Spanish Civil War. A newspaper review describes the character as a "drifter and drunk" who nonetheless displays courage and the capacity for compassion. ${ }^{74}$ Online newspaper archives for New Zealand end in 1949. However, a 1929 article reviewed a silent film The Poppies of Flanders featuring a remittance man and earl's son, "Brown," who is battling alcoholism in Africa. ${ }^{75}$ A girl fights for his salvation and Brown proves his worth, in turn, by giving his

\footnotetext{
${ }^{70}$ Julia A. Smith, "Land Ownership and Social Change in Late Nineteenth-Century Britain," The Economic History Review 53, no. 4 (2000): p.775.

${ }^{71}$ Zuehlke, Scoundrels, p.16.

${ }^{72}$ Selina Hastings, The Secret Lives of Somerset Maugham (London: John Murray (Publishers) Ltd, 2009).

73 "The World of the Theatre: Down and Across," Illustrated London News, 12 December 1959, p.864.

74 "The World of Books," The Sphere (UK), 25 August 1956, p.300.

75 "Majestic Theatre: Poppies of Flanders and Do Your Duty," Gisborne Times, 18 May 1929, p.6.
} 
The Graduate History Review 9, no. 1 (2020)

life to save the girl's lover during the Great War and earning the Distinguished Conduct Medal in the process. Whereas previous phases saw remittance men referred to as real and present entities, press reports in the inter- and post-war periods focus on memory and stereotype, represented within theatre and literature. Of note is the reoccurring theme of the reformed remittance man capable of love, compassion, nobility, and courage. The drunken and broken-down were transformed into the contemporary masculine ideal. By the end of this period, the era of the remittance man is all but over, their disreputable pasts seemingly rehabilitated, and their transformation into characters of popular mythology complete.

My examination of the English-speaking press across four colonies has enabled the identification and analysis of historical events that played significant roles in the creation of the archetypical remittance man. Families faced with reckless younger sons, decreasing incomes from land and assets, and fewer occupations for the upper class, sought alternative solutions for their rehabilitation. Those solutions were found in British colonies where, out of sight and mind and provided a regular supply of money, their sons might find salvation. Those sons, adrift with little prospect of inheritance or prestigious profession, found purpose at the outset of World War I. They abandoned a financially-supported existence to embark on "a noble experience involving all that they had been taught to exalt-glory, honor, and chivalry." ${ }^{176}$ Fighting for king and country served to rehabilitate remittance men more than exile and financial handouts. The Great War marked the end of the era of remittance men, but literature, theatre and stereotypes ensured memories of their existence lived on for another three decades.

But, what of the lived experiences of remittance men in New Zealand? To date, this is an aspect that has largely taken the form of anecdotal narratives. This is certainly true of the biographies contained in Hartley's Colonial Outcasts. Adopting a prosopographical approach, "the investigation of the common background characteristics of a group of actors in history by means of a collective study of their lives," I have endeavoured to uncover historical truth. ${ }^{77}$ Several key demographics were chosen to serve as useful indicators of remittance men's backgrounds and experiences. These include parentage, date of birth, country of origin, education, occupation at home and in New Zealand, remittance income,

\footnotetext{
${ }^{76}$ Mark Girouard, "A Return to Camelot," The Wilson Quarterly (1976-) 5, no.4 (1981): 188.

${ }^{77}$ Lawrence Stone, The Past and the Present (Boston: Routledge, 1981), pp.45-46.
} 
date of death, and cause of death. New Zealand Police Gazettes 1878 1945, New Zealand electoral rolls, British census records and available obituaries and personal papers provided additional background information.

A major challenge when researching remittance men lies in their identification being dependent on subjective observations rather than established facts. As such, no official records identify an individual as a remittance man. It was therefore necessary to engage with alternative sources. The New Zealand press proved the most fruitful hunting ground, as did tantalising, yet often vague, glimpses of remittance men in publications by settlers and visitors such as Lady Barker and Charles Wentworth Dilke. However, it is acknowledged that such sources do not provide a representative dataset, and their findings may exclude remittance men who lived out their exile without scandal or who successfully integrated into society. Furthermore, reports in the New Zealand press are, for the most part, considered subjective, as only a few contain admissions from individuals that they are being supported by family back home. What this research does provide is a counter-balance to the only extant detailed research in New Zealand by Hartley.

Dates of birth, standardised into decade for easier analysis, seem to correlate with the first phase of the press analysis. Individuals born in the 1850 s and 1860 s reached the age of majority during the 1870 s and $1880 \mathrm{~s}$, a time when their education was complete and an occupation considered. It is at this life stage that remittance men begin to appear in the New Zealand press. Ethnicity was established for 72 (45\%) of the 166 individuals. ${ }^{78}$ Where country of birth is known, over three-quarters hailed from England - a far greater proportion than the national composition of immigrant inflow from England during the period 1871-1890 of 55\%. Six percent hailed from Wales-larger than the inflow composition of less than $1 \%$, while $8 \%$ came from Scotland, significantly lower than the inflow composition of $21 \%$, and $5 \%$ from Ireland, markedly below the inflow composition of $22 \% .{ }^{79}$

Annual remittance amount is known for 18 (11\%) of the 166 individuals. ${ }^{80}$ Where this figure is recorded, 39\% received $£ 150-£ 200$ per annum. According to statistics contained in the 1875 Official Handbook, that income is comparable with the lower end of the pay scale

\footnotetext{
${ }^{78}$ Helen Leggatt, "Remittance Man Database," (2018).

${ }^{79}$ Jock Phillips, "Boom, depression, and immigration, 1871-1890," British \& Irish immigration, 1840-1914, 2014, www.nzhistory.net.nz/files/documents/peopling4.pdf, p.6.

${ }^{80}$ Helen Leggatt, "Remittance Man Database," (2018).
} 
The Graduate History Review 9, no. 1 (2020)

for a mine manager on the goldfields ( $£ 200-£ 500$ per annum), and that of an accountant ( $£ 3$ to $£ 5$ per week). Half (50\%) received an income of $£ 120$ or more, approximately double the sum received by single males employed as general labourers. ${ }^{81}$ Despite generous financial support, the lifestyles these incomes could support were dependent on a remittance man's priorities and whether additional finances were obtained through employment.

Receipt of remittances while employed was not unusual. Occupation was ascertained for half of all remittance men. ${ }^{82}$ Only three individuals claimed the occupation "gentleman" which indicates living off their own means. Several had professions such as dentist (1), theatrical manager (2), solicitor (2), salesman (3), accountant (1), or journalist (3). The majority were working as clerks (12) or labourers (13) —occupations far below their gentlemanly status. Other manual occupations listed include gardener (4), farmer (4), gum digger or sorter (3), and miner (3). The fact that most occupations were labourers or clerks suggests that few had the skills or motivation necessary to undertake specialised work. Neither do they appear to have been entrepreneurial: none were business owners, and only one was a merchant. Upper-class and aristocratic gentlemen believed themselves "above" working outside those professions generally taken up by their class. The fact that some would undertake manual work suggests financial motivation, little choice of employment within early colonial society, or a desire for male company.

A good level of income, an occupation, or both, was not enough to deter some remittance men from disreputable activities. Discharged from the British Army as unfit for service in May 1884, the aforementioned William Montague Davenport Howes was, by 1887 , living in New Zealand. The Electoral Rolls between 1893 and 1911 show his occupation as "gum digger." Giving evidence before a Royal Commission into the Kauri gum trade, Thomas Shore described the job of gum digging as "wretched" and "one of the last a man would take to." 83

\footnotetext{
81 '1875 Official Handbook', Statistics New Zealand, www3.stats.govt.nz/historic publications/1875-official-handbook/1875-officialhandbook.html\#idsect2 120509.

${ }_{82}$ Helen Leggatt, "Remittance Man Database," (2018).

${ }^{83}$ Kauri-gum Industry (Report and Evidence of the Royal Commission On), Appendix to the Journals of the House of Representatives, 1898 Session I, H-12, p.31. Retrieved 8 May 2020 from https://paperspast.natlib.govt.nz/parliamentary/AJHR1898-I.2.3.2.16/1.
} 


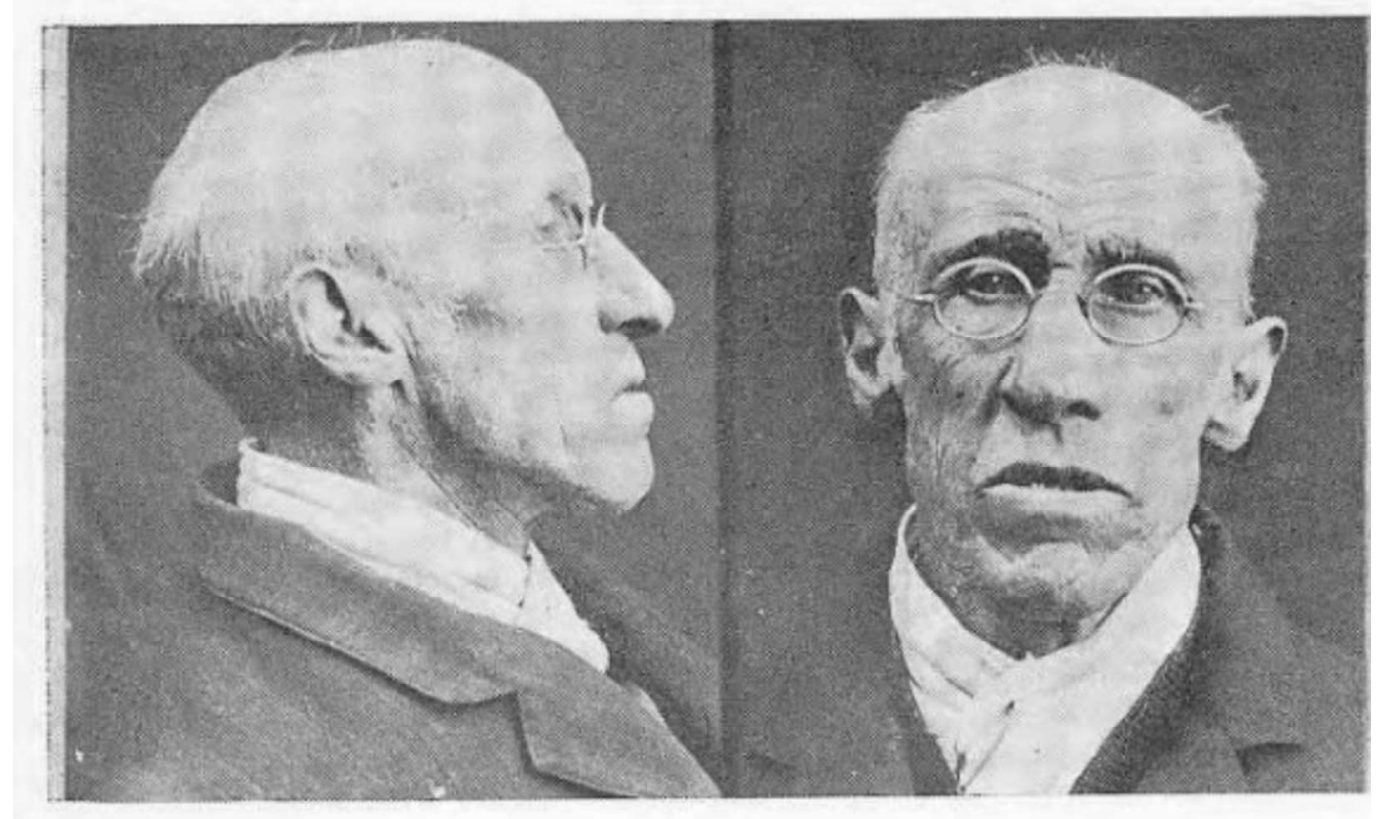

\title{
Howes, William Montague Davenport.
}

\author{
P.G. $17 / 428$. \\ F.P. Class $\frac{1}{1} \frac{\mathrm{A}}{\mathrm{A}}\left(\frac{\mathrm{IO}}{\mathrm{OO}}\right) 4$.
}

Figure 3: William Montague Davenport Howes, 1917. Source: New Zealand Police Gazette, Volume XLII, Issue 35, 5 September 1917, p.36. Reproduced with the kind permission of the National Library of New Zealand.

In subsequent years, William was charged with various offences including forging and uttering cheques, and two separate convictions for indecent assault on young males, for which he served two prison sentences of seven and ten years respectively. A native of England, Alfred Oswald Smith, working as a solicitor in New Zealand and receiving $£ 120$ a year in remittances, was age 49 when charged and convicted in 1915 for passing a forged cheque.$^{84}$ In receipt of $£ 200$ a year, Welshman Richard Owen Brigstocke was convicted three times for forgery and drunkenness. Arthur Henry Binstead, the son of London newspaper sub-editor and author Arthur Morris Binstead, received remittances of between $£ 15-£ 20$ each month while working as a debt collector and "medical specialist." In 1906, he pleaded with the judge presiding over his court case for fraudulent financial transactions to cable his father who would repay his

84 "A Dishonoured Cheque - A Remittance Man's Finances," New Zealand Herald, 23 January 1915, p.5. 
debts. ${ }^{85}$ Eight years later, in Australia, he pleaded guilty to drugging a pawnbroker's wife and persuading her to rob her husband of thousands of dollars of gold and jewellery. ${ }^{86}$ Despite receiving various degrees of financial support, not all remittance men could rely on allowances to fund their lifestyle. Renowned for their drinking habits, it was not unknown for remittance men to head straight to the bars upon receipt of funds, only to exhaust their funding before the next payment arrived. It is not unconceivable that the desire to maintain a lifestyle appropriate to their status led some to profit from criminal activity.

A striking finding is that, among the 71 (43\% of total) men whose cause of death could be ascertained, suicide is the major cause. Suicide accounted for $27 \%$ of all known causes, more than illness (14\%), accident (11\%), and drink (11\%). ${ }^{87}$ Could this figure be the result of more frequent reporting of sensational deaths? Perhaps so, the suicide rate compares dramatically with those of between $0.007 \%$ and $0.015 \%$ during the period $1870-1925 .^{88}$ It is acknowledged that the cause of death dataset is too small to extrapolate to deaths per 100,000, but it remains illustrative of a significantly disproportionate suicide rate among this social type. Despair and addiction to drink appear most frequently to have been the cause. Written in the pocketbook of James Priestman, who shot himself in the head, was "how much better to drop the curtain and put out the lights when the best of the play is over. The best is over. It has been a good play, and I have enjoyed it." ${ }^{19}$ Newspapers quoted acquaintances saying he was despondent due to his inability to secure employment. Drink, whether an existing addiction or a new-found solution to their predicament, was the cause of many a downfall. Twenty-six-year-old George Harold Brocklehurst, the son of wealthy shipping merchant Septimus Brocklehurst, committed suicide at Coker's Hotel, Christchurch, in July 1900. He had previously been hospitalized for delirium tremens. A letter left for his wife stated that his latest remittance payment had arrived but he had not collected it, because he feared that if he had it, he would spend it. A letter left for his father read "my wife and child are destitute. Lay

\footnotetext{
85 "Series of Defalcations - Remittance Man Pleads Guilty," New Zealand Herald, 2 February 1906, p.7.

86 "Stolen Jewellery," The Maitland Daily Mercury (NSW), 1 March 1924, p.12.

${ }^{87}$ Helen Leggatt, "Remittance Man Database," (2018).

88 David Victor Madle, "Patterns of Death by Accident, Suicide and Homicide in New Zealand 1860-1960, Interpretation and Comparisons," PhD thesis, Victoria University, Wellington, 1996, p.96. See also Jock Phillips, 'Suicide', Te Ara - the Encyclopedia of New Zealand, www.TeAra.govt.nz/mi/suicide/print.

89 "The Masterton Suicide," New Zealand Times (Supplement), 11 August 1891, p.1.
} 
every blame on me." ${ }^{90}$ The remittance men discovered in this research, and many in other British colonies, "represented the utter failure of elite masculinity to function in the modern world."91 Isolation from family and friends and life in a society indifferent to status proved disastrous for many young men.

Despite representing a small subset of New Zealand migrants, remittance men deserve further scrutiny, and demand incorporation into New Zealand's social history. Understanding their backgrounds, the historical contexts that forged their fates, and their colonial lives and deaths can only enrich current understandings of the colony's founding stock. Tracking their movements across time and nations is complicated by their outcast status, applied label, and subsequent anonymity. However, by better understanding the archetype as well as associated traits and behaviour, it is possible (when coupled with digital databases and record linkage) to begin to piece together a social history that has, until now, been ignored. This research has been limited in its scope, and has uncovered a particular subsection of remittance men-those whose behaviour was newsworthy. There are doubtless many more who did not attract such attention and successfully integrated into New Zealand society, as Hartley's research demonstrates. It is hoped that this initial foray into the lives of New Zealand's remittance men will encourage further research because, whether heroes or rogues, remittance men have an important story to tell about class, gender, family, and society at a time when New Zealand's colonial culture was being forged.

\footnotetext{
90 "Suicide in a Hotel - The Inquest," Star (Canterbury), 7 July 1900, p.7.
}

${ }^{91}$ Rico, Nature's Noblemen, 77. 
The Graduate History Review 9, no. 1 (2020)

\section{Bibliography}

\section{Primary Sources}

\section{Prosopographical Database-Compiler: Helen Leggatt}

"1861 England Census." Database. Ancestry. https://www.ancestry.com.

"1871 England Census." Database. Ancestry. https://www.ancestry.com.

"1881 England Census." Database. Ancestry. https://www.ancestry.com.

"1901 England Census." Database. Ancestry, https://www.ancestry.com.

"Birkett Family Tree." Database. Ancestry. https://www.ancestry.com.

"British Army Service Records." Database. Find My Past. https://www.findmypast.com.

"England \& Wales National Probate Calendar (Index of Wills and Administrations) 1858-1966." Database. Ancestry.

https://www.ancestry.com.

"Howes Family Tree." Database. Ancestry. https://www.ancestry.com.

"New Zealand Electoral Rolls 1890." Database. Ancestry. https://www.ancestry.com.

"New Zealand Electoral Roll 1896." Database. Ancestry. https://www.ancestry.com.

"New Zealand Electoral Roll 1900." Database. Ancestry. https://www.ancestry.com.

"New Zealand Army WWI Nominal Rolls, Vol: 15 Aug 1914-31 Dec 1915." Database. Ancestry. https://www.ancestry.com.

"New Zealand Notices of Deceased Estates 1897." Database. Ancestry. https://www.ancestry.com.

"New Zealand Police Gazettes 1878-1945." Database. Ancestry. https://www.ancestry.com.

"Passenger Lists Leaving UK 1890-1960." Database. Find My Past. https://www.findmypast.com.

"Williams Family Tree." Database. Ancestry. https://www.ancestry.com.

\section{Newspapers}

$\underline{\text { Australia - via Trove (https://trove.nla.gov.au) }}$

"Stolen Jewellery," The Maitland Daily Mercury (NSW), 1 March 1924.

Britain-via British Newspaper Archive (https://www.britishnewspaperarchive.co.uk) 
"Deaths." Homeward Mail (UK), 9 April 1888.

"Young Man's Betting Losses." Globe (UK), 9 February 1909.

"Losses of the Peerage." Gloucestershire Chronicle (UK), 1 January 1916.

"Our Bookshelf." The Sketch (UK), 10 September 1952.

"Films of the Week." Belfast News-Letter, 9 November 1954.

"How Much Pocket Money Should Children Have?" Belfast NewsLetter, 30 January, 1956.

"The World of Books." The Sphere, 25 August 1956

"The World of the Theatre: Down and Across." Illustrated London News, 12 December 1959.

Canada-via Newspaper Archive (https://newspaperarchive.com)

"Original Conundrums," Victoria Daily British Colonist, March 141868. "Pioneer Unsung Heroes Are Remittance Men." Medicine Hat News, 1 April 1953.

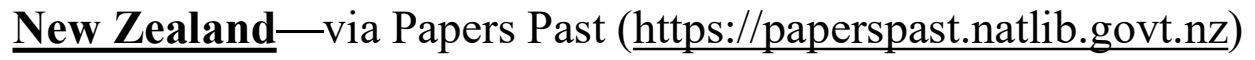

"News." West Coast Times, 4 March 1876.

"An Ex-Army Officer in Trouble: A Sad Case." Auckland Star, 4 May 1903.

"On Active Service." New Zealand Herald, 17 July 1915.

"Ten Years Imprisonment for Unnatural Offence." Nelson Evening Mail, 23 May 1919.

"Majestic Theatre: Poppies of Flanders and Do Your Duty," Gisborne Times, 18 May 1929.

\section{Secondary Sources}

Adam, Jack, Vivien Burgess, Dawn Ellis. Rugged Determination: Historical Window on Swanson, 1854-2004. Auckland, N.Z: Swanson Residents and Ratepayers Association Inc, 2004. Anderson, Clare. "Transnational Histories of Penal Transportation: Punishment, Labour and Governance in the British Imperial World, 1788-1939." Australian Historical Studies 47, no. 3 (2016): 381-397. 
The Graduate History Review 9, no. 1 (2020)

Arnold, Rollo. "Exodus from the Fringes: Emigrants to New Zealand 1839-1879." Typescript of a talk, n.d., https://sites.google.com/site/rolloarnold/migration.

Barker, Lady M.A. Station Amusements in New Zealand. London: William Hunt \& Co., 1873.

Belich, James. Making Peoples: A History of the New Zealanders: From Polynesian

Settlement to the End of the Nineteenth Century. Auckland, N.Z: Allen Lane, 1996.

Bruce, Anthony P.C. The Purchase System in the British Army, 16601871. London: Royal Historical Society, 1980.

Cain, P. J., and A. G. Hopkins. British Imperialism: Innovation and Expansion, 1688-1914. London: Longman, 1993.

Cannadine, David. The Decline and Fall of the British Aristocracy. London: Papermac, 1996.

Carr, Richard, and Bradley W. Hart. "Old Etonians, Great War Demographics and the Interpretations of British Eugenics, c. 1914-1939." First World War Studies 3, no. 2 (2012): 217-39.

Dilke, Charles Wentworth. Greater Britain Volume 1. London: Macmillan and Co., 1868. Project Gutenberg. http://www.gutenberg.org/ebooks/41755

Duthie, D. Wallace. "The Remittance Man." Nineteenth Century 46 (1899): 827-32.

Earp, George Butler. New Zealand: Its Emigration and Gold Fields. London: George Routledge \& Co., 1853.

Eden, H. C. My Wife and I in Queensland. London: Longman, Green \& Co., 1872.

Ekirch, A. Roger. Bound for America: The Transportation of British Convicts to the Colonies, 1718-1775. Oxford, UK: Oxford University Press, 1987.

Evershed, W. A. "Party and Patronage in the Church of England, 18001945: A Study of Patronage Trusts and Patronage Reform." ProQuest Dissertations Publishing, 1986.

Fairburn, Miles. The Ideal Society and Its Enemies: The Foundations of Modern New Zealand Society, 1850-1900. Auckland, N.Z:

Auckland University Press, 1989.

Feilding, William H. A. "What Shall I Do with My Son?" Nineteenth Century 14 (1883): 578-86.

Feilding, William H. A. "Whither Shall I Send My Son?" The Nineteenth Century 14 (1883): 65-77. 
Flavelle, Ryan. "Alberta Remittance Men in the Great War." In The Frontier of Patriotism: Alberta and the First World War. Eds. Adriana A. Davies \& Jeff Keshen. University of Calgary Press, 2016.

Gallagher, Thomas F. "'Cardwellian Mysteries': The Fate of the British Army Regulation Bill, 1871." The Historical Journal 18, no. 2 (1975): 327-48.

Girouard, Mark. "A Return to Camelot." The Wilson Quarterly (1976-) 5, no. 4 (1981): 178-189.

Grady, C. Jill. "Remittance Men and the Character of Cannon Beach." Oregon Historical Quarterly 108, no. 1 (2007): 68-87.

Gray, Herbert Branston. The Public Schools and the Empire. London: Williams \& Norgate, 1913.

Hadley, Elaine. "Natives in a Strange Land: The Philanthropic Discourse of Juvenile Emigration in Mid-Nineteenth-Century England." Victorian Studies 33, no. 3 (1990): 411-439.

H. G. Hart, The New Annual Army List, and Militia List (London: John Murray, 1863). National Library of Scotland. https://digital.nls.uk/105741571.

Hartley, Nell. Colonial Outcasts: A Search for the Remittance Men. Morrinsville, N.Z: Arrow, 1993.

Hastings, Selina. The Secret Lives of Somerset Maugham. London: John Murray (Publishers) Ltd, 2009.

Hunt, Philip. "Social Relations and Class Divisions in the Te Aroha District." Historical Research Unit-University of Waikato, 2016.

Kain, Jennifer. "The Ne'er-Do-Well: Representing the Dysfunctional Migrant Mind New Zealand 1850-1910." Studies in the Literary Imagination 48, no. 1 (2015): 75-92.

Madle, David Victor. "Patterns of Death by Accident, Suicide and Homicide in New Zealand 1860-1960, Interpretation and Comparisons." Victoria University of Wellington, 1996.

Mangan, J. A. 'Benefits Bestowed'?: Education and British Imperialism. Oxford, UK: Routledge, 2012.

Maxwell-Stewart, H. "Convict Transportation from Britain and Ireland 1615-1870." History Compass, 8 (2010): 1221-1242.

McAloon, Jim. "Class in Colonial New Zealand: Towards a Historiographical Rehabilitation." New Zealand Journal of History 38, no. 1 (2004): 3-21.

Morpeth, Philip Allan. The "Waiheathens" at Gallipoli. Tauranga City Libraries Research Collections, 2008. http://tauranga.kete.net.nz/remembering_war/documents/show/42 
The Graduate History Review 9, no. 1 (2020)

9-ebook-epubformat-the-waiheathens-at-gallipoli-by-allan-pmorpeth

Morris, Edward E. Austral English: A Dictionary of Australasian Words Phrases and Usages, with Those Aboriginal-Australian and Maori Words Which Have Become Incorporated in the Language and the Commoner Scientific Words That Have Had Their Origin in Australasia. London: Macmillan, 1898.

Olssen, Erik. "Where to from Here? Reflections on the TwentiethCentury Historiography of Nineteenth-Century New Zealand." New Zealand Journal of History 26, no. 1 (1992): 54-77.

Otley, C. B. "The Social Origins of British Army Officers." Sociological Review 18, no. 2 (1970): 213-39.

Otley, C. B. "The Educational Background of British Army Officers." Sociology 7, no. 2 (1973): 191-209.

Oxford English Dictionary. "Remittance Man." Oxford University Press, July 2018.

Parker, Roy. Uprooted: The Shipment of Poor Children to Canada, 1867-1917. Bristol, UK: Policy Press, 2010.

Phillips, Jock. "Suicide." Te Ara-the Encyclopedia of New Zealand, http://www.TeAra.govt.nz/mi/suicide/print.

Phillips, Jock. "Boom, depression, and immigration, 1871-1890." British \& Irish immigration, 1840-1914, 2014, http://www.nzhistory.net.nz/files/documents/peopling4.pdf.

Phillips, Jock, and Terry Hearn. Settlers: New Zealand Immigrants from England, Ireland and Scotland 1800-1945. Auckland University Press, 2013.

"Punch's Essence of Parliament." Punch. 5 August 1871, https://archive.org/stream/punch60a61lemouoft\#page/n333.

Rico, Monica. Nature's Noblemen: Transatlantic Masculinities and the Nineteenth-Century American West. U.S.: Yale University Press, 2013.

Rico, Monica. "Sir William Drummond Stewart: Aristocratic Masculinity in the American West." Pacific Historical Review 76, no. 2 (2007): 163-91.

Rouse, William H. D. A History of Rugby School. New York: Scribner, 1898.

Royal Commission on the Law Practice of Sale Exchange Resignation of Ecclesiastical Benefices. Report of the Commissioners Appointed to Inquire into the Law and Existing Practice as to the Sales, Exchange, and Resignation of Ecclesiastical Benefices. London: George Edward Eyre \& William Spottiswoode, 1879. 
https://hdl.handle.net/2027/umn.31951002137499c. Accessed via Hathitrust.org 22 November 2019.

Smith, Julia A. "Land Ownership and Social Change in Late NineteenthCentury Britain." The Economic History Review 53, no. 4 (2000): 767-76.

Spiers, Edward M. The Late Victorian Army, 1868-1902. Manchester, UK: Manchester University Press, 1992.

Stone, Lawrence, The Past and the Present. Boston: Routledge, 1981.

Thompson, F. M. L. English Landed Society in the Nineteenth Century. London: Routledge, 1963.

Tucker, Albert V. "Army and Society in England 1870-1900: A Reassessment of the Cardwell Reforms." Journal of British Studies 2, no. 2 (1963): 110-41.

Vito, Christian G. De, Clare Anderson, Ulbe Bosma. "Transportation, Deportation and Exile: Perspectives from the Colonies in the Nineteenth and Twentieth Centuries." International Review of Social History 63, S26 (2018): 1-24.

Zeisler, Karl F. "Mr Langhorne—a Prairie Sketch." Quarterly Review of the Michigan Alumnus 65 (1959): 229.

Zuehlke, Mark. Scoundrels, Dreamers \& Second Sons: British Remittance Men in the Canadian West. Toronto: Dundurn Press, 2001.

\section{Websites}

"1875 Official Handbook." Statistics New Zealand. https://www3.stats.govt.nz/historic publications/1875-officialhandbook/1875-official-handbook.html.

Barry Patemen, "Private Williams of Waihi," New Zealand Cricket Museum. http://nzcricketmuseum.co.nz/williams.

"John Nathaniel (Nat) Williams," Waihi Museum. http://www.waihimuseum.co.nz/museum-and-research/world-wari/john-nathaniel-williams.

Kauri-gum Industry (Report and Evidence of the Royal Commission On), Appendix to the Journals of the House of Representatives, 1898 Session I, H-12, p.31. https://paperspast.natlib.govt.nz/parliamentary/AJHR1898I.2.3.2.16/1.

"The Morpeth Waiheathens (WWI) 14-0333," Tauranga Memories: Remembering War. Tauranga City Libraries. 
The Graduate History Review 9, no. 1 (2020)

http://tauranga.kete.net.nz/remembering_war/images/show/8934the-morpeth-waiheathens-wwi-14-0333. 